\title{
COMPARETTIA BENNETTII (ORCHIDACEAE: ONCIDIINAE), A NEW RECORD FOR ECUADOR
}

\author{
Marco M. Jiménez ${ }^{1,4-5}$, Luis Ocupa Horna² \& Leisberth Vélez-AbarcA ${ }^{3,4}$ \\ ${ }^{1}$ Orquideario La Paphinia, Avenida del Ejército y Juan Izquierdo, Zamora, \\ Zamora Chinchipe, 190102, Ecuador \\ ${ }^{2}$ Departamento de Orquideología, Centro de Investigación en Biología Tropical y Conservación - \\ CINBIOTYC, Piura, Perú \\ ${ }^{3}$ Carrera de Biología, Universidad Estatal Amazónica (Sede El Pangui), El Pangui, Ecuador \\ ${ }^{4}$ Grupo Científico Calaway Dodson: Investigación y Conservación de Orquídeas del Ecuador, \\ Quito, Ecuador \\ ${ }^{5}$ Author for correspondence: mmjimenez473@gmail.com Carrera de Biología,
}

\begin{abstract}
Comparettia bennettii, a previously known species from Peru and Bolivia, was recently recorded in the premontane forests of southeastern Ecuador. We provide a Lankester Composite Digital Plate (LCDP), photos, taxonomic comments, and an updated description of the species.

Resumen. Comparettia bennettii, previamente conocida de varias colecciones de Perú y Bolivia, se encontró recientemente en los bosques premontanos al sureste del Ecuador. Se proporciona una lámina digital compuesta estilo Lankester (LCDP), fotografías, comentarios y una descripción actualizada de la especie.

Key Words / Palabras clave: Amazonia, bosque premontano, Condor mountain chain, Cordillera del Cóndor, premontane forests, Stigmatorthos, southeastern Ecuador, taxonomía, taxonomy
\end{abstract}

Introduction. The neotropical genus Comparettia Poepp. \& Endl. was described in 1835 (Poeppig \& Endlicher 1835). The genus is recognized by the small, terete, unifoliate pseudobulbs, without foliaceous sheaths at the base, the inflorescence arising from the base of the pseudobulb, the sepals extended into an elongate, slender spur-sheath at the base and the spur of the lip double and inserted in the sepaline spursheath (Dodson \& Luer 2005).

Chase et al. (2008) combined the species previously treated in Chaenanthe Lindl., Diadenium Poepp. \& Endl., Neokoehleria Schltr., Pfitzeria Senghas, Scelochiloides Dodson \& M.W.Chase, Scelochilopsis Dodson \& M.W.Chase, Scelochilus Klotzsch, and Stigmatorthos M.W.Chase \& D.E.Benn., into a broader interpretation of Comparettia, based on phylogenetic analyses by Williams et al. (2001), which revealed the genera centered around Comparettia are all embedded within Scelochilus (Pupulin \& Merino 2010). This new circumscription encompasses 73 species that mostly differ in floral details, such as the length of the nectar spur (Chase et al. 2008).

Chase and Bennett (1993) described the monotypic genus Stigmatorthos based on S. peruviana M.W.Chase \& D.E.Benn. from a collection from Pasco region in Peru. When Stigmatorthos was published by Bennett and Christenson (1995), it was proposed as distinct from other genera in the Oncidiinae by the unusual linear lip with a short nectar spur constricted at the base, the pentagonal callus and the vertical slit-like stigma. In 2008, Chase et al. transferred S. peruviana to Comparettia as C. bennettii (M.W.Chase \& D.E.Benn.) M.W.Chase \& N.H.Williams, the previously epithet of $C$. peruviana Schltr. being occupied (Chase et al. 2008). Because of the absence of the holotype, a lectotype was designated from an isotype deposited in the Missouri Botanical Garden (Trujillo 2014).

A new record, Comparettia bennettii from Ecuador, was collected during a research aimed to assess the orchid diversity of the Cordillera del Cóndor in southeast Ecuador.

\section{TAXONOMIC TREATMENT}

Comparettia bennettii M.W.Chase \& N.H.Williams, Lindleyana 21(3): 27.2008. SStigmatorthos peruviana 


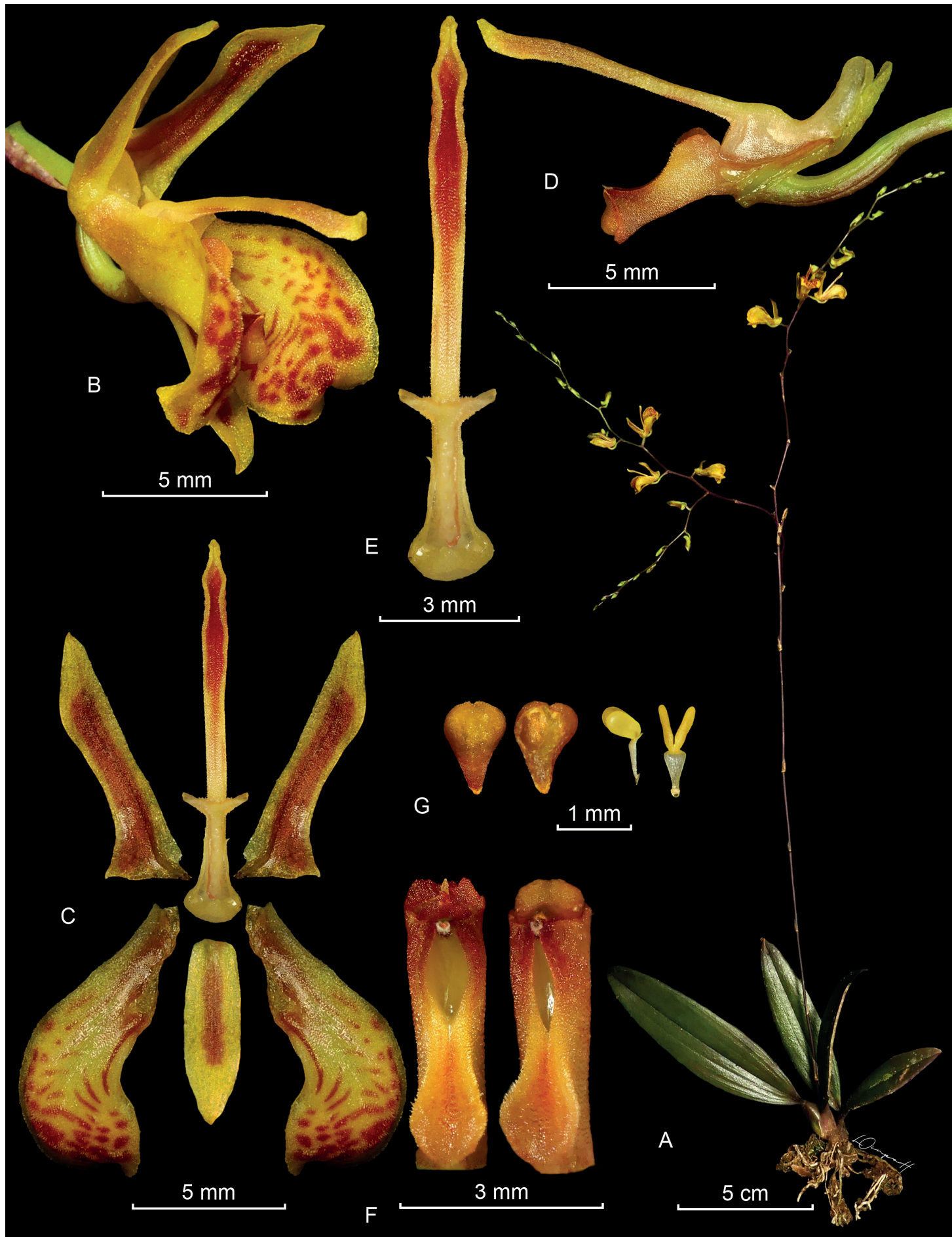

Figure 1. Comparettia bennettii (M.W.Chase \& D.E.Benn.) M.W.Chase \& N.H.Williams. A. Habit. B. Flower, lateral view. C. Perianth dissected. D. Pedicel, ovary, column, and lip, lateral view. E. Lip, adaxial view. F. Column, frontal and overhead view. G. Anther cap and pollinia. LCDP by Luis Ocupa Horna from photos by Marco M. Jiménez. 
M.W.Chase \& D.E.Benn., Lindleyana 8(1): 4-7, f. 1-2. 1993 (Fig. 1-3). TYPE: Peru, Pasco, Oxapampa, Aguachini, $26 \mathrm{~km} \mathrm{S.SE} \mathrm{of} \mathrm{Puerto} \mathrm{Bermudez,} \mathrm{above}$ Río Azupizu, 700 m, 20 Oct 1990, O. del Castillo sub D. Bennett 4748 (holotype: SEL, lost.; isotype: MOLspirit, designated as lectotype by Trujillo 2014).

Epiphytic herb, erect, caespitose, up to $36 \mathrm{~cm}$ tall. Roots slender, numerous, white, branching, flexuous, $0.7-1.3 \mathrm{~mm}$ in diameter. Pseudobulbs dark green suffused with brownish purple, ovate to narrowly ovate or elliptic, cylindrical, $0.6-1.5 \times 0.4-0.9 \mathrm{~cm}$, unifoliate at the apex, enclosed at the base by distichous sheaths $8.0-16 \times 4.0-6.0 \mathrm{~mm}$, the upper ones foliaceous, the lower ones scarious. Leaves fleshy, dark green suffused with purplish brown adaxially, purplish brown abaxially, $4.6-8.8 \times 1.2-2.4 \mathrm{~cm}$, completely green when young, oblong-elliptic, conduplicate, sometimes slightly sulcate and shiny adaxially, infolded at its base into an indistinct petiole, apex acute, asymmetrical. Inflorescences up to $30 \mathrm{~cm}$ long, produced from the base of the pseudobulb, a panicle of successive, 6-23 flowered racemes, rachis flexuous, peduncle brownish purple, $5.5-15.9 \times 0.2 \mathrm{~cm}$, enclosed by several glumaceous floral bracts, $1.0 \times 2.0 \mathrm{~mm}$, triangularovate. Ovary pedicellate, terete, sigmoid, $9 \times 1 \mathrm{~mm}$. Flowers small, non-resupinate, sepals dark greenish yellow with a broad brown-mahogany stripe, petals dark greenish yellow with pale discontinued brown lines, uniting near the apex, lip whitish yellow with a broad reddish-brown stripe from the apical half, column reddish brown, yellowish at the tabula infrastigmatica, anther yellowish green with a touch of brown. Dorsal sepal oblong, subacute, $6.1 \times 1.9 \mathrm{~mm}$. Lateral sepals transversely oblong constricted at the upper margin, oblique, divergent, $8.3 \times 2.7 \mathrm{~mm}$. Petals strongly oblique-falcate, obovate-flared, minutely hispid, $4.9 \times$ $9.3 \mathrm{~mm}$. Lip $12 \times 2 \mathrm{~mm}$, linear-oblanceolate, minutely hispid, subacute at the apex, subparallel to the column, extended into a short, saccate spur, constricted at the base with a transversely pentagonal callus. Column $7.4 \times 1.3 \mathrm{~mm}$, straight, the lower ventral half swollen into a finely hispid, concave tabula infrastigmatica, extended into a thin foot, stigma slit-like, longitudinal, clinandrium shortly cucullate, margins rose. Anther $1.3 \mathrm{~mm}$ long, obtriangular. Pollinia 2, yellow, stipe spathulate, convex, viscidium minute.

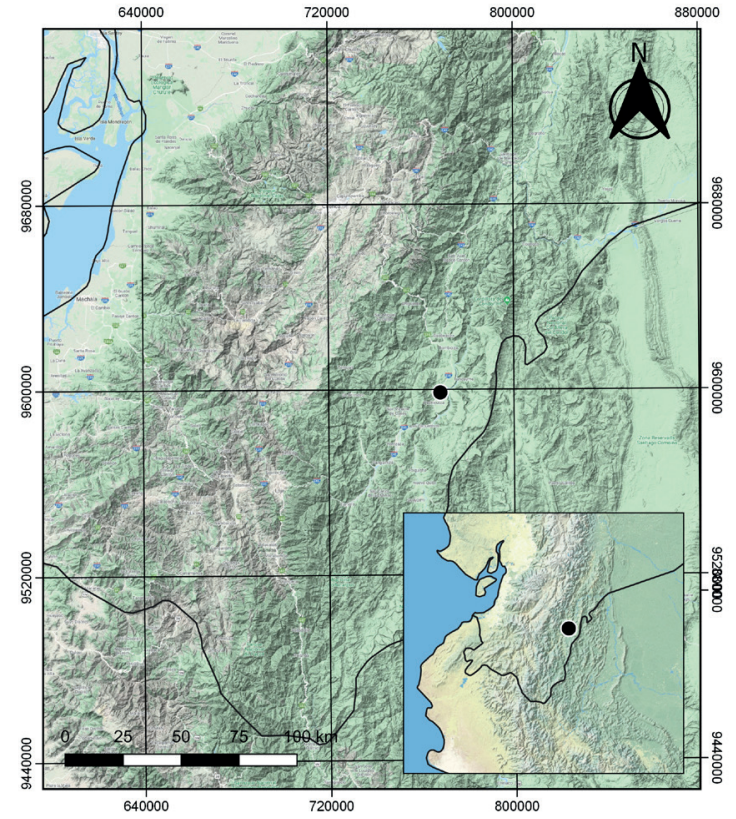

Figure 2. Distribution map of Comparettia bennettii in Ecuador. Map created by Irwing Saldaña.

EXAMINED MATERIAL: Ecuador. Zamora Chinchipe: Cordillera del Cóndor, 893 m, 04 June 2020, L. Vélez 24 (ECUAMZ).

Comparettia bennetti occurs in Peru (Chase \& Bennett 1993, Bennett \& Christenson 1995), Bolivia (Vásquez et al. 2003) and Ecuador (Fig. 2), where it was found as an epiphyte on small trees of premontane forests from a sandstone plateau of the Cordillera del Cóndor in the Zamora Chinchipe Province. It was also found in the Alto Nangaritza region of the same province, observed by author Jiménez and vouchered with a photograph. Therefore, the geographical distribution of this taxon extends much farther north in the Amazon drainage basin. The populations of C. bennettii in Ecuador grow in unprotected areas where mining activity is rampant, hence it could be considered as endangered following the IUCN criteria.

The morphology of leaves and flowers is consistent between populations and individuals; meanwhile, the size of the plants, leaves, length of the inflorescences, number of flowers per raceme, and color tone of the flowers is variable. In the original description of Chase and Bennett (1993), the 


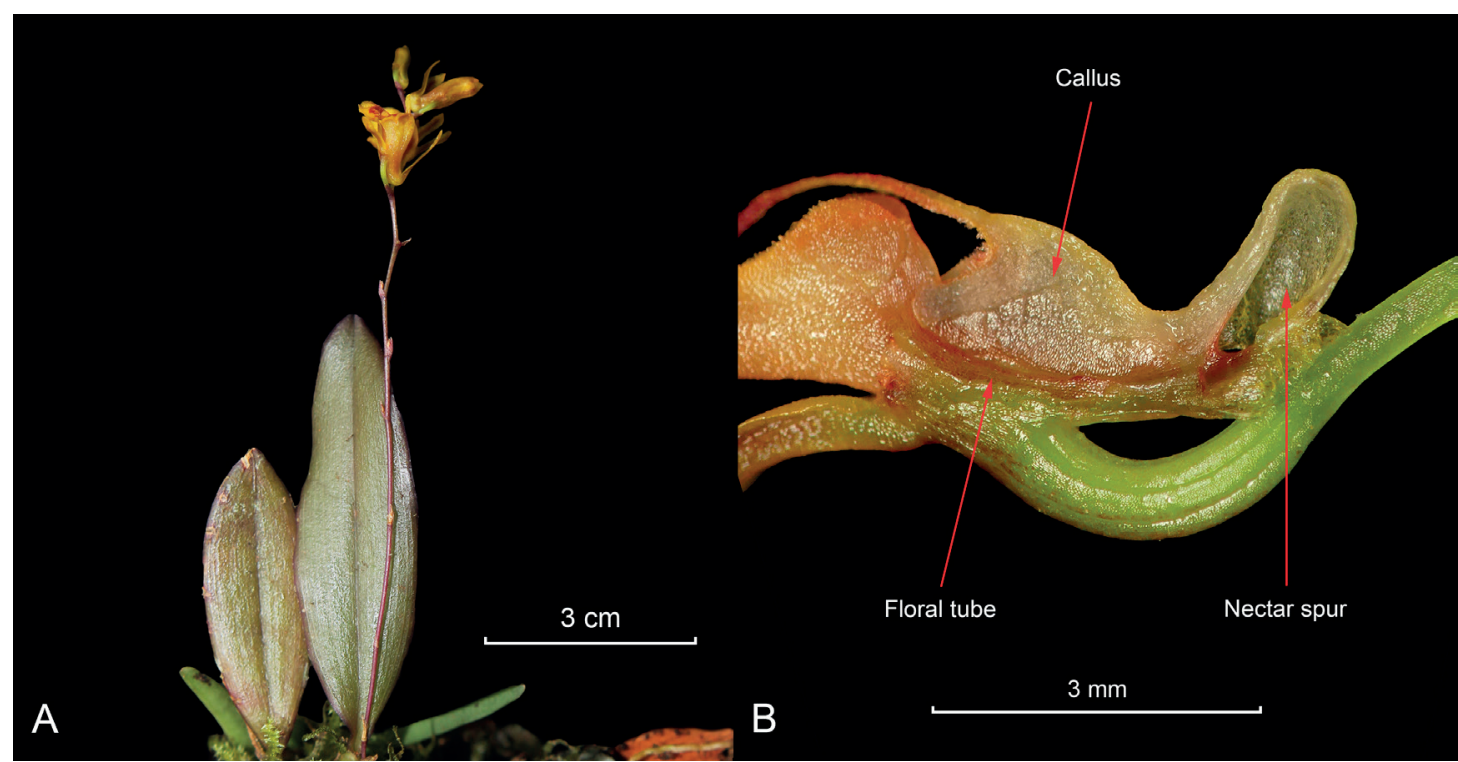

Figure 3.Comparettia bennettii (M.W.Chase \& D.E.Benn.) M.W.Chase \& N.H.Williams. A. Smaller specimen in flower.

B. Longitudinal section of the lip with callus, floral tube and nectar spur in detail. Photos by LeisberthVélez-Abarca (A) and M. Jiménez (B).

resupination of the flowers of Comparettia bennettii is not mentioned; nevertheless, this feature was observed in the examined specimens (Fig. 1, 3). Also, Chase and Bennett (1993) remarked on the existence of nectar horns; meanwhile, those are not referred in the description of Bennett and Christenson (1995) and are not evidenced in the dissected flowers. In the observed flowers, the nectar spur is only an extension of the lip that is fused to the column foot and is not formed by the bases of the lateral sepals as in other related genera. The floral tube, situated between the infrastigmatic tabula and the callus, suggests that this structure is important for pollinators (Fig. 3).

AcKnOwledgments. We thank Mark Wilson for helping with language corrections and other observations in this manuscript. We also thank Luis Baquero for his suggestions in the text. We thank Irwing Saldaña for his help with this investigation. To the Ministerio del Ambiente (MAE) for granting the Research Permit No. 037-2019-IC-FLO-FAUDPAZCH-UPN-VS/MA. The authors also acknowledge the reviewers of this manuscript for helping with comments and corrections for this work.

\section{LiterATURE CITED}

Bennett, D. E. \& Christenson, E. A. (1995). Stigmatorthos peruviana M.W.Chase \& D.E.Benn. Plate 388 In: Icones Orchidacearum Peruviarum, Plates 201-400. Lima, Peru: Published by A. Pastorelli de Bennett.

Chase, M. W. \& Bennett, D. E. (1993). Stigmatorthos peruviana - A new genus and species in the Scelochilus Alliance (Orchidaceae: Oncidiinae). Lindleyana, 8(1), 4-7.

Chase, M. W., Williams, N. H., Neubig, K. M. \& Whitten, W. M. (2008). Taxonomic transfers in Oncidiinae to accord with Genera Orchidacearum, Volume 5. Orchids, 77(12), 27.

Dodson, C. H. \& Luer, C. A. (2005). Flora of Ecuador: Orchidaceae: Genera Aa-Cyrtidiorchis. Göteborg, Sweden: Department of Plant and Environmental Sciences, University of Gothenburg.

Poeppig, E. F. \& Endlicher, S. L. (1835). Nova genera ac species plantarum, quas in regno Chilensi Peruviano et in terra Amazonica: annis MDCCCXXVII ad MDCCCXXXII, Volumen I. Leipzig: Sumptibus Friderici Hofmeister.

Pupulin, F. \& Merino, G. (2010). Comparettia sotoana (Orchidaceae: Oncidiinae), a new Ecuadorian species. Lankesteriana, $9(3), 400$.

Trujillo, D. (2014). Annotated list of Orchidaceae types of the Bennett collection at the Forestry Herbarium MOL. 
Lankesteriana, 14(1), 70.

Vásquez, R., Ibisch, P. L. \& Gerkmann, B. (2003). Diversity of Bolivian Orchidaceae - a challenge for taxonomic, floristic and conservation research. Organisms, Diversity and Evolution, 3(2), 93-102.

Williams, N. H., Chase, M. W., Fulcher, T. \& Whitten, W. M. (2001). Molecular systematics of the Oncidiinae based on evidence from four DNA sequence regions: expanded circumscriptions of Cyrtochilum, Erycina, Otoglossum, and Trichocentrum and a new genus (Orchidaceae). Lindleyana, 16(2), 127. 
LANKESTERIANA 